\title{
Research on Social Media Tourism Marketing in the Post-epidemic Period
}

\author{
Xie Xiaoluan \\ School of Journalism and Communication, Nanjing Normal University, Nanjing, China \\ 309004184@qq.com \\ Diserahkan: 7 Juni 202 1; Direvisi: 27 Juni 2021 ; Diterima: 27 Juni 2021
}

\begin{abstract}
Since 2020, the outbreak of covid-19 has changed the operation mode of many industries, and also has a great impact on the global tourism industry. At the same time, it also promotes the transformation of the tourism industry, which is more dependent on the real economy, to the Internet economy. The use of social media for tourism marketing is a hot spot in recent years, and the outbreak of the epidemic has intensified the development of this model. This paper analyzes the characteristics of social media to explain why it is more suitable for tourism marketing than traditional media, and summarizes the tourism marketing strategies and means of social media. Social media has rich forms of expression, such as text, pictures, audio, video, live broadcast, etc., which can be selected according to the nature of tourism destination. Through the use of precision marketing, word-of-mouth marketing, celebrity effect and other marketing strategies, it can also improve the audience's willingness to travel during the post epidemic period, and promote the recovery and development of tourism.
\end{abstract}

Keywords: Communication Form, COVID-19, Marketing Strategy, Social Media, Tourism Marketing.

\begin{abstract}
Abstrak
Sejak tahun 2020, merebaknya covid-19 telah mengubah mode operasi banyak industri, dan juga berdampak besar pada industri pariwisata global. Pada saat yang sama, juga mendorong transformasi industri pariwisata, yang lebih bergantung pada ekonomi riil, ke ekonomi Internet. Penggunaan media sosial untuk pemasaran pariwisata adalah hot spot dalam beberapa tahun terakhir, dan wabah epidemi telah mengintensifkan pengembangan model ini. Makalah ini menganalisis karakteristik media sosial untuk menjelaskan mengapa lebih cocok untuk pemasaran pariwisata daripada media tradisional, dan merangkum strategi pemasaran pariwisata dan sarana media sosial. Media sosial memiliki bentuk ekspresi yang kaya, seperti teks, gambar, audio, video, siaran langsung, dll, yang dapat dipilih sesuai dengan sifat tujuan wisata. Melalui penggunaan pemasaran presisi, pemasaran dari mulut ke mulut, efek selebriti dan strategi pemasaran lainnya, juga dapat meningkatkan keinginan audiens untuk bepergian selama periode pasca epidemi, dan mempromosikan pemulihan dan pengembangan pariwisata.

Kata Kunci: Bentuk Komunikasi, COVID-19, Strategi Pemasaran, Media Sosial, Pemasaran Pariwisata.
\end{abstract}




\section{INTRODUCTION}

Since 2020, the outbreak of COVID-19 has hit the global economy hard and changed many industries. Most countries have severely restricted import and export trade to combat the outbreak. Various industries in China have experienced a month-long suspension of work and production, and the government strictly controlled the cross-border and inter-provincial movement of personnel. These policies had affected the tourism industry which has always been more dependent on the real economy, into a state of stagnation. The UN World Tourism Organization released a statement saying that the global tourism industry lost $\$ 320$ billion in revenue from January to May 2020 alone due to the novel coronavirus epidemic, more than three times the amount lost during the global financial crisis in 2009, threatening the livelihoods of millions of people (UNWTO, 2020).

According to World Health Organization (WHO) recommendations, numerous countries limited people's travel, closed tourist attractions, and suspended economic activities/public events during the COVID-19 epidemic (UNWTO, 2020). Pandemic or health-related difficulties, such as fear of COVID-19 (FCV) and perceived danger, have put destinations/cities under lockdown in a number of countries (Bae \& Chang, 2020; UNWTO, 2021). Extensive COVID-19 social media promotion might influence travelers' perceptions of danger, altering their behavior, perception, and attitude (fear, overreaction, pessimism) (Bhati et al., 2020; Hassan \& Soliman, 2020). Furthermore, despite the fact that research on customer brand engagement (CBE) has yielded important findings, most studies to date have focused on CBE in free-market, everyday resulting in a major information gap about its appearance in non-regular settings, such as pandemics/crises As a result, it is critical to analyze the function of $\mathrm{FCV}$, perceived risk, and social media on attitude/CBE, which then affects co-creation and travel intentions in a COVID-19 pandemic situation in order to revive tourism demand, as studied in this study.

Since the second half of 2020, the epidemic situation in China has slowed down, so travel restrictions have been gradually relaxed in various places, and the tourism industry has entered a stage of recovery and development. The shock of the epidemic prompted the tourism industry to reshuffle, and small tourism enterprises with weak economic strength were forced to withdraw from the market. The marketing and profit model of the whole industry has gradually shifted from offline to online. One of the important marketing means is to use social media to publicize tourism destinations, develop "cloud tourism" industry, improve users' willingness to travel on the spot, break through the restrictions of real economy development, and achieve online revenue generation of tourism industry.

\section{LITERATURE REVIEW}

Social media and Web 2.0 are two popular buzzwords as well as technological concepts, which have brought about pervasive changes in business-to-business communication, business to-customer communication, and customerto-customer communication (Kietzmann, Hermkens, McCarthy, \& Silvestre, 2011). In this era of social media, the Internet has evolved from a broadcasting medium to a participatory platform which allows people to become the "media" themselves for collaborating and sharing information (Li \& Wang, 2011; Thevenot, 2007). Being one of the "mega trends" that has significantly impacted the tourism system, the role and use of social media in travelers' decision making and in tourism operations and management have been widely discussed in tourism and hospitality research. Leung et all., (2013) through their research explaining about the influence and use of social media in visitors' decision making as well as in tourism operations and management have been widely explored in tourism and hospitality research as one of the "mega trends" that have dramatically altered the tourism system.

The study examines and analyzes all existing social media-related research articles published in academic publications between 2007 and 2011, with a focus on tourism and hospitality. Based on a content analysis of the analyzed articles from the perspectives of both customers and suppliers, 
according to the findings of the article, consumer-centric studies generally focused on the use and influence of social media in the research phase of travelers' vacation planning process. Supplierrelated research has primarily focused on promotion, management, and research functions, with few studies addressing product distribution. The findings of the study clearly indicate the strategic value of social media for tourism competitiveness. The study also benefits academia and industry by identifying research gaps in existing research and offering a research agenda for the future.

Furthermore, the tourism industry is currently being affected by the COVID-19 pandemic and the study that examines the major changes in tourism promotion and marketing in the epidemic had been done by many researchers. Toubes et all., (2021) reveal that online information sources have gained weight over contacting friends and relatives, and a significant development in digitization is projected, with traditional travel firms being overtaken by online platforms, except for specialized and advisory services. Furthermore, in the longer future, technologies such as virtual reality (VR) and artificial intelligence (AI) may play a growing role. The study explains that aspects such as personalization, digitalization, security, use of online channels, new technologies and the redesign of products and strategies will be the keys to continue marketing in the tourism sector from now on. Traditional media were already being displaced by digital media; this crisis has accelerated this process. Communication should also benefit from the use of online media to reach potential tourists, with contact being increasingly direct and without intermediaries (Toubes, Vila, \& Brea, 2021).

In the tourism crisis marketing literature, image repair strategies used by destination marketers during previous image crises were divided into three broad categories: 1. Source/Media strategies which are used when officials seek to influence the destination's media coverage patterns in one of the media outlets (such as developing media relations, blocking the journalists' access, threating the reporters); 2. Message strategies which concentrate on tackling the essence of the place's negative image (such as acknowledging the negative image, initiating events, and delivering a countermessage); and audience strategies which focus on creating affinity to a specific audience (such as concentrating on a resilient audience, use patriotism, appealing to specific audience's values). The most popular strategies used during previous crises concentrated on the message, then on the source/media and last were the audience strategies (Avraham \& Ketter, 2016; Beirman \& Van Walbeek, 2011). In counter to these past findings, the present study found that audience-based strategies were the most popular strategies that destinations around the world chose to combat the COVID-19 challenges. Source strategies were barely found, nor were the message strategies that are usually focused on cognitive and rational messages. As a result, there seems to be a serious doubt that most of the previous image repair models we know, and which were mainly designed to deal with a short-term crisis, were appropriate to deal with prolonged global crises (Sigala, 2020). Unlike previous crises, during the COVID-19 crisis, both the marketers and the target audience share the same feelings and face together the same challenges, establishing the basis for audience-focused marketing strategies (Hang et al., 2020).

\section{METHODS}

In this study, we used the descriptive research design, which is a method of research that attempts to describe and understand items in line with reality. The descriptive method is used because the data analysis is presented in a descriptive manner. We collect data from various sources such as documents, releases, news sources, and previous research. In this study, we emphasize the literature review. A literature review can broadly be described as a more or less systematic way of collecting and synthesizing previous research. An effective and well-conducted review as a research method creates a firm foundation for advancing knowledge and facilitating theory development (Webster \& Watson, 2002). It can also help to provide an overview of areas in which the research is disparate and interdisciplinary. In addition, a literature review is an excellent way of synthesizing research findings to show evidence on a meta-level and to uncover areas in which more research is 
needed, which is a critical component of creating theoretical frameworks and building conceptual models (Snyder, 2019).

Palmatier et al., (2018) suggest that a quality literature review must have both depth and rigor, that is, it needs to demonstrate an appropriate strategy for selecting articles and capturing data and insights and to offer something beyond a recitation of previous research. In addition, they state that a quality literature review needs to be replicable, that is, the method must be described such that an external reader could replicate the study and reach similar findings. Lastly, they state that a literature review must be useful for scholars and practitioners. However, evaluating different types of literature reviews can be challenging.

\section{RESULT AND DISCUSSION \\ DEVELOPMENT OF SOCIAL MEDIA}

Social media is an evolving information medium, and definitions of social media currently vary due to the different focuses of different studies. The concept of social media first originated abroad and initially referred to a platform that could support online participation of user groups in opinion exchange and content production. Since then, with the development of network information technology and changes in users' social habits, the functions and forms of social media have been enriched, and the subdivision types have become more and more numerous, so the concept of social media has been changing and cannot be clearly defined. According to the research perspective of this article, social media can be defined as "an online network platform or application based on web2.0 information technology that can conduct real-time content production, information exchange, and two-way interaction in multiple ways."

In 1997, the earliest foreign social networking site "Six Degrees" was established, whose social principle is the Six Degrees of Separation proposed by Stanley Milgram, a professor of psychology at Harvard University in 1967. In 2002, Fang Xingdong, Wang Junxiu, Sun Jianhua and others launched Blog China (www.blogchina.com). Since then, China entered a new phase of Internet communication. The blog established the concept of "personal page", where individuals could set up their own homepage, publish content and leave messages on this basis, and for the first time, domestic users transformed from "audience" to "user". In 2003, "Friendster", which focused on stranger social networking, emerged, bringing users higher social capital by establishing weak interpersonal relationships on the Internet, thus triggering a wave of social networking for all. In the same year, "Myspace", a social networking site that provided users with a variety of personalized space designs, was born and quickly grew to become the second largest social networking site in the world within four years.

The next year, one of today's social media giants, Facebook, was founded. It copied the offline real interpersonal network to the online, which can not only replace the offline for low-cost management, but also open up an interactive platform where real and virtual, acquaintances and strangers coexist. The constantly rich functions meet people's diverse social needs. As a result, Facebook has been a huge success worldwide, with over 1 billion users within 8 years of its establishment. Although Facebook failed to enter China, but in 2005, Tencent developed QQzone, which became popular nationwide, and gradually shifted the focus of development from computer websites to mobile Internet devices.

With the advent of the mobile Internet era, social media shifted from web hyperlinks to a grid of interpersonal relationships on smart devices, and the proliferation of relationships with individuals as nodes became increasingly evident. 2006 saw the birth of Twitter, which created a virtual discussion forum where users could freely express their opinions and the media properties of social applications were enhanced. Three years later, China's Sina Company developed "microblog", becoming the leader of the same type of social media. In 2010, KIK messenger application based on the rapid construction of contact components of mobile phone address book appeared. On the basis 
of KIK technology, Tencent developed WeChat application by virtue of users accumulated by QQ. The strong relationship structure based on real interpersonal network makes the number of WeChat users expand rapidly. With the continuous enrichment and strengthening of functions, WeChat has become an indispensable social media in national life.

With the generalization of social concepts and applications, marketing methods based on social media are gradually playing an important role. Compared with the past, the proportion of Chinese netizens using social media to record their lives, share news and purchase products has increased significantly. The social media marketing of tourism enterprises has a relatively large mass base, while the characteristics of social media itself make it play an increasingly important role in tourism marketing.

\section{SOCIAL MEDIA FEATURES}

With the development of Internet technology, today's social media are becoming more and more diverse and refined. Other functional (e.g. online payment, online shopping, knowledge sharing) applications are also gradually developing social functions. Tan Tian divides social models into four categories: platform-based, community-based, tool-based, and ubiquitous (Tan \& Zhang, 2017). Platform type emphasizes media attributes and can provide public discussion space, such as Microblog. Community type includes blood, geography, business, interest and other interpersonal relationships, in which strong and weak relationships coexist, such as WeChat, QQ, Douban, Zhihu, etc.Tool type uses social thinking to develop tool products. Social is an incidental function, and providing services is the focus of the product. This type of product includes Taobao, Netease Cloud Music, Hupao Sports, etc. The ubiquitous type does not refer to a single medium, but a variety of mediums that contain social elements. Although social media is gradually showing a dazzling trend, but no matter what type of media contains the following basic characteristics, and therefore become a marketing method that can not be ignored.

\section{Rich Form \& Rapid Dissemination}

Since the last century, the carrier of social media has evolved from electronic computers to a variety of smart devices, and the form of communication has also undergone an evolution from pictures and text to audio, video, live streaming, VR and AR. Today's social media can integrate multiple forms of communication, breaking through the limitations of traditional media's single form of communication and bringing users an all-round audio-visual experience. Compared with traditional media, which requires users to receive messages at a specific time and place, social media is more flexible and free. With the maturity of $5 \mathrm{G}$ technology, users can connect to the Internet more quickly and at a lower cost. As long as users have an intelligent mobile terminal, they can connect to the Internet to receive information anytime and anywhere.

Using social media for tourism marketing, company can choose the corresponding communication form according to the characteristics of different media, launch a network-wide publicity, increase the exposure rate of information, and leave an intuitive impression in the minds of users and form a psychological implication. At the same time, the production process of social media marketing is easier and the production cycle is shorter, which is conducive to the instant dissemination of information. Propagating different tourism products for target users of different media is also more conducive to the rapid spread of information among similar groups and improving the efficiency of dissemination.

\section{Large Amount of Information \& Strong Interactivity}

Traditional media are limited by many factors in the process of information dissemination. The amount of information that can be disseminated within the specified length or space is limited, and the information can only be transmitted from the media to the public in a one-way manner. Audience 
feedback channels are scarce, and the dissemination effect cannot be measured intuitively. Platformbased social media provides a public platform for all users to exchange opinions. As long as a topic becomes the center of discussion, it can attract huge attention in a short period of time and deliver multiples of information than traditional media in the process of two-way communication. In social media, each user integrates the identity of information publisher and receiver, and can simultaneously input and output information. Social media marketing information is not a linear mode of communication, but a spiral mode of communication that actively adjusts the content after receiving feedback from users, constantly increasing the amount of information and improving the relevance of information, with both parties being the main subject of communication. High interactivity can facilitate tourism enterprises to conduct real-time user consumption willingness evaluation, so as to timely adjust marketing strategies and seek the best communication effect.

\section{Low Marketing Costs}

The way social media spreads information is based on the development of communication technology and Internet technology. With the progress of the times and the development of technology, electronic computers and intelligent terminal devices have tended to become fully popular. The 47th China Statistical Report on Internet Development shows that as of December 2020, the size of China's Internet users reached 989 million, and the Internet penetration rate reached 70.4\%, of which the size of instant messaging users reached 981 million, which provides a vast customer base for social media advertising and marketing (CNNIC, 2021).

Traditional media has a strict ad production process, long production and placement cycle, so the cost of advertising and marketing is relatively high. At the same time, due to the lack of smooth and effective feedback channels, the communication effect of traditional media advertising is often only reflected by changes in actual product sales measured by professional organizations, increasing the cost of trial and error in advertising. Social media advertising, on the other hand, is more flexible and versatile, with relatively lower initial investment in buying ad space and producing ad text. After the ads are put into the market, real-time feedback can be quickly provided through the number of likes, retweets and comment content. In 2020, the market size of China's online advertising reached 496.6 billion yuan, and although the growth rate slowed down under the influence of factors such as the new pneumonia epidemic, the year-on-year growth rate was also as high as $14.4 \%$, which shows that online advertising enables enterprises to gain more profits and promote better and faster development, so it is highly favored by enterprises.

\section{SOCIAL MEDIA TOURISM MARKETING STRATEGY}

Social media marketing is a new type of marketing activity carried out by social media and commodity companies in the context of the Internet with the help of user participation and user social capital (Wei, 2019). In the process of frequent interaction on social media platforms, the relationship between commodity enterprises and users is strengthened, while the use of social media can also create a pro-people image and good reputation of the enterprise, improve the trust of potential users in the enterprise's products, and thus increase commodity sales and promote the enterprise brand. The social media tourism marketing strategy, on the other hand, is a marketing strategy developed through the cooperation between social media platforms and tourism enterprises or departments, based on the characteristics of the market environment, the characteristics of the tourism destination itself and the characteristics of users.

The characteristics of social media make it possible to use a variety of marketing strategies when conducting tourism promotion. During the epidemic, tourism companies or destinations adopted a variety of marketing strategies on social media, such as precision marketing, word-of-mouth marketing, celebrity effects, etc., based on the national conditions that the flow of people across the country has shrunk significantly. 


\section{Precision Marketing}

Precision marketing usually refers to the goal of driving consumers to participate efficiently and realizing one-to-one marketing to consumers in the context of big data. Big data mining technology is used to carry out a large amount of consumer data collected from outside or existing by enterprises. Analyze and optimize the marketing strategy based on the results of the analysis (Jing, 2017). The implementation of social media precision marketing strategies generally includes three steps: First, collect data. Commodity companies need to extensively collect consumer-related data on social platforms such as Micro-blog, WeChat, and TikTok. The second is to analyze the data. Companies need to input the collected data into precision marketing models, use big data mining technology and other means to analyze them in detail, and extract effective information such as consumer behavior characteristics and consumer preferences from them. The third is to accurately distribute advertisements. According to users' consumption information, companies distribute different advertising information to different consumers, precisely cater to consumers' consumption preferences, and increase the conversion rate between "advertising and consumption".

Take Micro-blog as an example. It can record users' personal information and historical behaviors, predict users' interests and preference through waterfall analysis of various structured data, and target ads that interest users, which can extend user's visit time, increase their stickiness.

The key to precision marketing is to identify the interests of tourists, evolve the emotional link between tourism companies and tourists into emotional dependence, and realize economic profits while cultivating a stable customer base for the company.

\section{Word-of-mouth Marketing}

At present, China's goods and service resources are extremely rich, and consumers often face multiple choices. Therefore, consumers will take the initiative to conduct word-of-mouth searches in the process of consumption decision-making. Platform or social media is the search platform commonly used by consumers. Among them, the validity of the information source, the relevance of the topic or content, and the user's perceived risk assessment are the triple criteria for consumers to judge the product and the company's reputation (Dai \& Han, 2015). Positive word-of-mouth will increase consumer purchases willingness and negative evaluation tend to dispel potential purchase behaviors. User's shopping experience is easy to regenerate word-of-mouth evaluation under internal stimulus or external inducement, re-dissemination cycle to build a word-of-mouth system, and the online word-of-mouth landing platform develops into a larger "word-of-mouth field". Tourism companies or departments can conduct word-of-mouth guidance and control corresponding to the word-of-mouth judgment standards to improve their brand image and attractiveness.

During the epidemic period, the offline tourism industry is difficult to sustain. Therefore, tourism enterprises are switching to the online one after another. The staff of the scenic spot use social media to transmit the natural and cultural scenery, and publicize the complete epidemic prevention measures of the scenic spot, so as to maintain a good brand image, deepen the public memory, maintain the tourism willingness of the audience, and pave the way for the rebound of the number of tourists after the epidemic.

\section{Celebrity Effect}

According to Maslow's hierarchy of needs theory, the linking behavior of social network users is jointly affected by internal motivations and external motivations, but external motivations have the greatest impact on users' continuous link behavior intentions. Therefore, the network link behavior of social media users is easily influenced by others, and then produces a herd effect.

Celebrity effect refers to the expansion of the impact of an event due to the participation of celebrities or the idea of people imitating celebrities. The communication characteristics of social 
media can maximize the influence of celebrities, attract the attention of many followers, and achieve the purpose of publicity and promotion of tourist destinations.

During the post epidemic period, many tourism enterprises and departments invited tourism image ambassadors or netizens to visit the scenic spots, and their social media became natural billboards. The appeal of celebrities play a great role in the publicity of scenic spots. For example, about four months ago, a Tibetan guy named Ding Zhen accidentally became popular on the Internet. The photo of him riding a white horse on the plateau became a hot topic last winter. Subsequently, the number of tourists to Litang County, Ding Zhen's hometown, soared in the short term, and Ding Zhen was also hired as Litang's image ambassador, responsible for long-term tourism promotion. This becomes a classic example of celebrity effect.

\section{SOCIAL MEDIA TOURISM MARKETING APPROACH}

As mentioned above, social media has rich forms of communication, but the communication effect and application scope of various forms are obviously different.

\section{Picture and Text}

The combination of pictures and text makes reasonable use of visual effects. It is the most common form of publicity, with the widest scope of application, and is suitable for publicizing the cultural characteristics of the scenic spot. Images and texts forms often appear in WeChat official account, Moments of Friends, Micro-blog. The pictures are often very exquisite, which can stimulate people's desire for travel. The text description can also clarify the historical and cultural background of the scenic spot and add humanistic color.

According to a research report on tourism demand trends jointly issued by the Tourism Research Center of the Chinese Academy of Social Sciences and Tencent Cultural and Creative, the average overall tourism motivation after the epidemic has increased by $4.0 \%$ compared with 2019. Among them, "understanding culture and history, rich knowledge" has increased by $7.4 \%$. From this point of view, the graphic and text communication mode of social media is significantly higher than the offline travel.

\section{Video}

Travel videos can establish a series of interactive ceremonies among users. First, through virtual and real physical presence, video viewers can simulate travel scenarios online and ask for relevant information, or they can go to physical attractions with their community friends to complete the travel experience through their physical presence. Secondly, tourist destinations often focus on specific features of scenic spots for video promotion, triggering tourists to imitate. Through the reproduction of sound and pictures, the scale of interaction between users continues to expand, and the destination takes advantage of the trend to realize communication and marketing. Finally, travel videos can also arouse emotional resonance among users and stimulate their willingness to travel by delivering beautiful scenery and telling moving stories (Zeng \& Li, 2019).

Common forms of video travel communication include short videos and Vlogs, which are often posted on social platforms such as TikTok, Kuaishou, MicroBlog and Xiaohongshu. The duration of short videos is often within one minute. The limitation of duration makes the content more inclined to pure scenery or travel experience that is simple and easy to imitate. Tourism marketing is realized by triggering emotional resonance and imitation intent of the audience. For example, there is a tavern in Xi'an where customers can drop the bowl directly after drinking. And a light rail in Chongqing that passes directly through the middle of the residential building becomes a spectacle. Video shooting of such scenic spots can easily cause imitation by social users.

The duration of vlog is usually about 1-5 minutes, and the widened duration allows it to carry more content and can achieve a panoramic presentation of tourist destinations. The interpretation 
style and tour experience of the person who appear on the screen can also increase the interest of the scenic area, attract the attention of the audience, and stimulate their willingness to travel.

\section{Live Broadcast}

Social media live broadcast is a new mass communication model that has emerged in recent years. Through this model, viewers can intuitively experience scenic spots as if they are on the scene. During the live broadcast, the two parties can interact in real time, and the audience can ask the host questions online, or point out the details they want to see, and browse the beautiful scenery online. In addition, the rise of live streaming has also inspired the tourism industry to sell souvenirs and local specialties online to make up for the loss caused by the decrease in offline tourists.For example, in March, 2020, Suzhou Museum conducted two live broadcast on Taobao live platform, with a total of 580000 people watching, which led to the sales of more than 1000 cultural and creative products, and became a successful case of online "cloud tourism".

\section{CONCLUSION}

In summary, the rich forms of social media and low advertising production costs have opened up new areas of development for the tourism industry during the post-epidemic period. From the perspective of a risk society, emergencies such as large-scale epidemics, social conflicts and climate change are difficult to predict. Such incidents often have a huge impact and blow to the tourism industry. Therefore, social media tourism marketing is becoming more and more important to the tourism industry. In the future, tourism companies or departments should strengthen the publicity of health and safety in scenic spots on social media, and use VR, AR or other new technologies to continuously enhance user experience, and accelerate the realization of the full-line development of the tourism industry.

\section{ACKNOWLEDGMENT}

I would like to thank my supervisor, Professor Zhuang Xi, for her guidance during my writing of the paper, and thank the Organizing Committee of the 3rd Jakarta Communication Conference and Jurnal Audiens for their support.

\section{REFERENCES}

Avraham, E., \& Ketter, E. (2016). Marketing tourism for developing countries: Battling stereotypes and crises in Asia, Africa and the Middle East. Palgrave-McMillan.

Beirman, D., \& Van Walbeek, B. (2011). Bounce back: Tourism risk, crisis and recovery management guide. PATA.

CNNIC. (2021, February 3. The 47th China Statistical Report on Internet Development. Retrived from: http://www.cnnic.net.cn/hlwfzyj/hlwxzbg/hlwtjbg/202 102/P0202 10203334633480 104.pdf.

Dai, S., Han, X. (2015). The application of word-of-mouth marketing in the brand image shaping of publishing houses in the context of socialization. China Publishing Journal, (15) 57-60.

Retrived from:

https://kns.cnki.net/kcms/detail/detail.aspx?FileName=ZGCB201515019\&DbName $=\mathrm{CJFQ}$ 2015

Hang, H., Aroean, L., \& Chen, Z. (2020). Building emotional attaching during COVID-19. Annals of Tourism Research, 83 (83), 103006. https://doi.org/10.1016/j.annals.2020.103006

Jing, L. (2017).Research on Internet Marketing Strategy Based on Big Data Precision Marketing. Journal of Commercial Economics (11) 46-47. Retrived from: https://kns.cnki.net/kcms/detail/detail.aspx?FileName=SYJJ20171 1015\&DbName=CJFQ2O 17

Kietzmann, J. H., Hermkens, K., McCarthy, I. P., \& Silvestre, B. S. (2011). Social media? Get serious! Understanding the functional building blocks of social media. Business Horizons, 54(3), 241251. 
Leung, D., Law, R., \& Lee, H. A. (2011). The perceived destination image of Hong Kong on Ctrip.com. International Journal of Tourism Research, 13(2), 124-140.

Leung, D., Law, R., Hoof, H. v., \& Buhalis, D. (2013). Social Media in Tourism and Hospitality: A Literature Review. Journal of Travel \& Tourism Marketing, 3-22.

Palmatie, R. W., Houston, M., \& Hulland, J. (2018). Review articles: Purpose, process, and structure. Journal of the Academy of Marketing Science, 1-5.

Sigala, M. (2020). Tourism and COVID-19: Impacts and implications for advancing and resetting industry and research. Journal of Business Research, 117,312-320.

Snyder, H. (2019). Literature review as a research methodology: An overview and guidelines. Journal of Business Research, 333-339.

Tan, T., Zhang, Z. (2017). The current situation, development and trends of social media in China. Editorial Friend, (1) 20-25. doi:10.13786/j.cnki.cn14-1066/g2.2017.01.003

Toubes, D. R., Vila, N. A., \& Brea, J. A. (2021). Changes in Consumption Patterns and Tourist Promotion afterthe COVID-19 Pandemic. J. Theor. Appl. Electron., , 1332-1352.

UNWTO. (2020, 06 28). Retrieved 06 30, 2020, from unwto.com: https://www.unwto.org/news/impact-of-covid-19-on-global-tourism-made-clear-as-unwtocounts-the-cost-of-standstill

Webster, J., \& Watson, R. (2002). Analyzing the past to prepare for the future: Writing a literature review. Management Information Systems Quarterly, 3.

Wei, Y. (2019). Research on Relevant Strategies of Social Media Marketing from the Perspective of Relationship. PhD dissertation. Southeast University. doi:10.27014/d.cnki.gdnau.2019.001626

Yusuf, M. K., \& Liman, A. (2015). Yusuf, Muhammad Kabir \& Liman, Abdullahi. (2015). Virtual Cultural Resonance" as an Evidence for "Media Effect by Consent": Notes on Media Audience Theories and Proposing New Communication Model. The International Journal Of Humanities E Social Studies, 3(11).

Zeng, L., Li, J. (2019).The Rise of Douyin Travel Short Videos from the Perspective of Interactive Ceremony Chain. Media, (16) 44-46. Retrived from:

https://kns.cnki.net/kcms/detail/detail.aspx?FileName=CMEI201916019\&DbName= 